Our Nature (2011) 9: 156-167

\title{
Physico-chemical Parameters of Koshi River at Kushaha Area of Koshi Tappu Wildlife Reserve
}

\author{
D. Thapa Chhetry ${ }^{1^{*}}$ and J. Pal ${ }^{2}$ \\ ${ }^{1}$ Department of Zoology, P.G. Campus, T.U., Birantnagar, Nepal \\ ${ }^{2}$ Department of Zoology, North Bengal University, India \\ *E-mail: thp_damodar@rediffmail.com
}

Received: 20.07.2010, Accepted: 19.11.2011

\begin{abstract}
The Koshi river is the major tributaries of the Ganges which originates from the snowy peaks of Tibetan plateau in the central Himalayas. Its total catchment area is $60,400 \mathrm{~km}^{2}$, of which $28,140 \mathrm{~km}^{2}$ lies in Nepal, while the remainder is situated in Tibet. It passes from Nepal to India via the Koshi Tappu Wildlife Reserve area of Nepal. It destroys large area through floods, especially in India. This paper deals with the air temperature and phyco-chemical parameters like temperature, transparency, $\mathrm{pH}$, oxygen, carbondioxide, alkalinity, hardness, chloride and biological oxygen demand of water of Koshi river at Kushaha area of Koshi Tappu Wildlife Reserve. The water temperature was recorded maximum in summer season but the transparency, $\mathrm{pH}$, dissolved oxygen, total alkalinity and total hardness were recorded maximum in winter season. Similarly, free carbondioxide was maximum in rainy season and chloride and biological oxygen demand were recorded maximum in summer season. The air temperature and water temperature had positive and significant correlation with free carbondioxide and biological oxygen demand. Dissolved oxygen had positive and significant correlation with $\mathrm{pH}$, total alkalinity and total hardness. Similarly, total alkalinity had positive and significant correlation with transparency, total hardness, chloride etc.
\end{abstract}

Key words: Koshi River, physico-chemical parameters.

\section{Introduction}

Though vast numbers of limnological investigations have been carried out in other countries, only a few works have been done in Nepal. Loffler (1969) reported the dominance of calcium among cations, low chloride and less than $1 \mu \mathrm{g} / 1$ phosphorus from the high altitude lakes of Mount Everest region. Lohman et al. (1988) studied pre and post monsoon limnological characteristics of lakes of Pokhara and Kathmandu valleys. They recorded low alkalinity and conductivity in the lakes of Pokhara valley. McEachern (1994) reported $8.4 \mathrm{pH}, 0.03 \mathrm{mg} / \mathrm{l}$ phosphate and $8.5 \mathrm{mg} / \mathrm{l}$ dissolved oxygen in Narayani, a lowland
$(<1000 \mathrm{~m})$ river of Nepal. Aryal and Lacoul (1996) studied water quality and diversity of diatoms in Punyamati river. They reported high $\mathrm{pH}$, total hardness, BOD at polluted site, where transparency and dissolved oxygen were low. Ormerod et al. (1996) reported the $\mathrm{pH}$ range 7.3 to 8 , chloride $0.4 \mathrm{mg} / 1$ to $1.4 \mathrm{mg} / \mathrm{l}$, nitrate $0.06 \mathrm{mg} / \mathrm{l}$ to $0.28 \mathrm{mg} / \mathrm{l}$, and phosphate $0.02 \mathrm{mg} / \mathrm{l}$ to $0.04 \mathrm{mg} / 1$ from the highland $(>2000 \mathrm{~m})$ rivers of Nepal.

The study site, Kushaha area of Koshi river is inside the Koshi Tappu Wildlife Reserve and lies between 26 $37^{\prime} 14.4^{\prime \prime} \mathrm{N}$ latitude and $87^{\circ} 01^{\prime} 26.1$ "E longitude (Fig. 1). 
D. Thapa Chhetry and J. Pal / Our Nature (2011) 9: 156-167

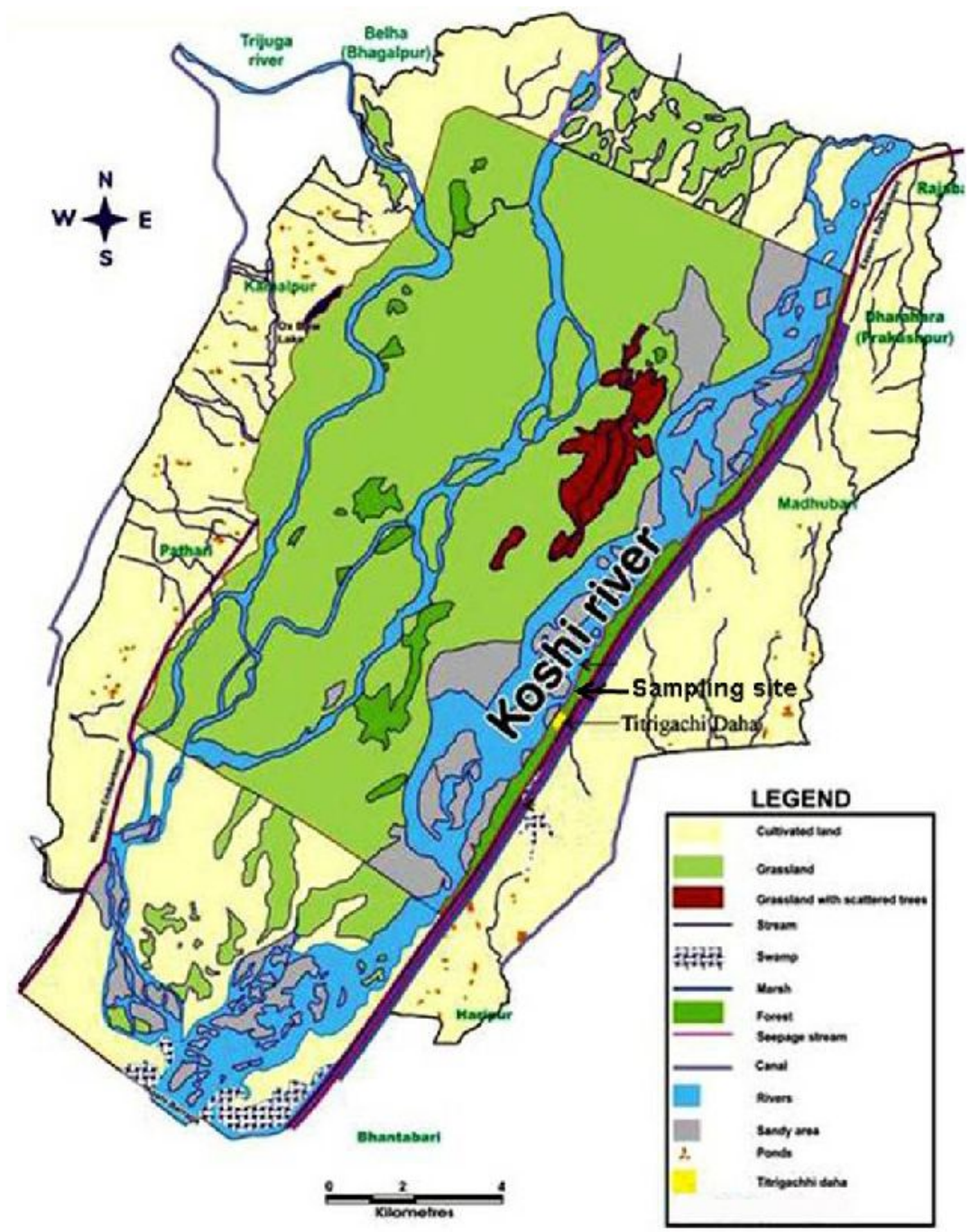

Figure 1. Map showing study site, Kushaha area of Koshi river inside the Koshi Tappu Wildlife Reserve.

The headquarter of Koshi Tappu Wildlife Reserve is also located at Kushaha.

\section{Materials and methods}

The physico-chemical parameters were studied from July, 2002 to June, 2004. The water for physico-chemical studies were collected between 8 am and $11 \mathrm{pm}$, once in every month at regular interval and analysed in the field. However, the BOD test after 5 days incubation in the incubator was done in the laboratory of Post Graduate Campus, Biratnagar. Transparency, air temperature and water temperature were recorded between 12 noon and 1 p.m. For the analysis of physico-chemical parameters, methods of Welch (1952), Michael (1984), Trivedi and Goel (1984), Adoni et al. (1985) and APHA (1998) were adopted. 


\section{Thapa Chhetry and J. Pal / Our Nature (2011) 9: 156-167}

\section{Results \\ Air temperature}

The minimum air temperature was $18.3 \pm 0.594^{\circ} \mathrm{C}$ in the month of January and maximum $32.7 \pm 0.427^{\circ} \mathrm{C}$ in the month of May during the first year study period (July, 2002 to June, 2003) (Tab. 1). The air temperature increased a little in August then decreased from September to January. Again it increased from February to May then a slight decrease was recorded in June and increased a little in July during the first year study period (Tab. 1). Similar pattern of air temperature was observed in the second year study period (July, 2003 to June, 2004) also (Tab 2). The maximum air temperature was $33.1 \pm 0.497^{\circ} \mathrm{C}$ in the month of May and minimum $18.5 \pm 0.452^{\circ} \mathrm{C}$ in the month of January during the second year study period. The air temperature had positive and significant correlation with water temperature $(\mathrm{r}=$ $0.9811, \mathrm{P}<0.01)$, free carbon dioxide $(\mathrm{r}=$ $0.8259, \quad \mathrm{P}<0.01)$ and biological oxygen demand $(\mathrm{r}=0.7196, \mathrm{P}<0.01)$ but inverse and significant correlation with transparency $(\mathrm{r}=-0.8885, \mathrm{P}<0.01), \mathrm{pH}(\mathrm{r}=$ $-0.5670, \mathrm{P}<0.01)$, dissolved oxygen $(\mathrm{r}=$ $0.8424, \mathrm{P}<0.01)$, total alkalinity $(\mathrm{r}=$ $0.9264, \mathrm{P}<0.01)$, total hardness $(\mathrm{r}=-0.6072$, $\mathrm{P}<0.01)$ and chloride $(\mathrm{r}=-0.3624, \mathrm{P}<0.10)$ (Tab. 3).

The seasonal variation in air temperature was little higher $\left(30.13^{\circ} \mathrm{C}\right)$ in rainy season in comparison to that of summer $\left(29.55^{\circ} \mathrm{C}\right)$ and lowest in winter season during the first year study period. During the second year study period, the air temperature was recorded little higher in summer than rainy season and lowest was found in winter (Tab. 4).

\section{Water temperature}

The lowest surface water temperature was $14.3 \pm 0.550^{\circ} \mathrm{C}$ in the month of January and highest $29.1 \pm 0.320^{\circ} \mathrm{C}$ in the month of August during the first year study period (July, 2002 to June, 2003). The water temperature increased a little in August then decreased from September to January. Again it increased from February to May and then a slight decrease was recorded in June followed by an increase in July during the first year study period (Tab. 1). Similar pattern of water temperature was observed during the second year study period (July, 2003 to June, 2004) also (Tab. 2). The maximum water temperature was $29.2 \pm 0.549^{\circ} \mathrm{C}$ in the month of August and the minimum $15.2 \pm 0.648^{\circ} \mathrm{C}$ in the month of January during the second year study period (July, 2003 to June, 2004). The water temperature had positive and significant correlation with free carbon dioxide $(\mathrm{r}=0.7784, \mathrm{P}<0.01)$ and biological oxygen demand ( $\mathrm{r}=0.7122, \mathrm{P}<0.01)$, but inverse and significant correlation with transparency $(\mathrm{r}=-0.8498, \mathrm{P}<0.01), \mathrm{pH}(\mathrm{r}=$ 0. 4981, $\mathrm{P}<0.05)$, dissolved oxygen $(\mathrm{r}=-0$. $8073, \mathrm{P}<0.01)$ total alkalinity $(\mathrm{r}=-0.9000$, $\mathrm{P}<0.01)$ and total hardness $(\mathrm{r}=-0.5763$, $\mathrm{P}<0.01$ (Tab.3). Seasonally, water temperature was maximum in summer followed by rainy and winter seasons during the whole study period.

\section{Transparency}

It was found that the transparency increased from the month of August to January and then decreased from February to July during the first year (Tab. 1) and the second year study periods (Tab. 2). The maximum transparency was $54.1 \pm 0.770 \mathrm{~cm}$ in the month of January and minimum $13 \pm 0.337$ $\mathrm{cm}$ in the month of July during the first year study period. During the second year study 


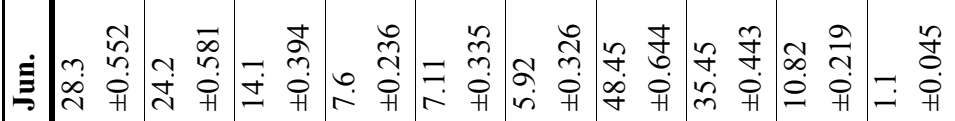

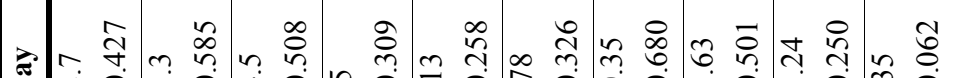

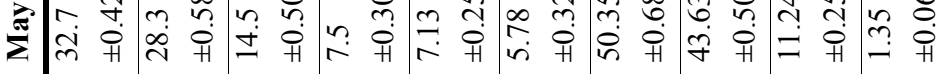

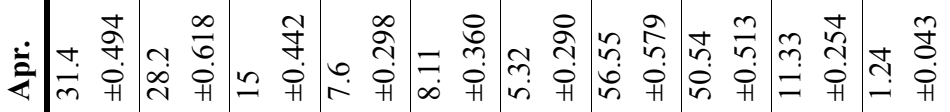

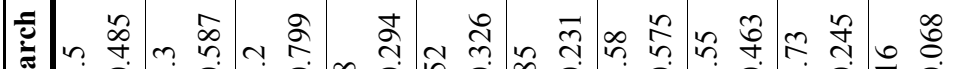

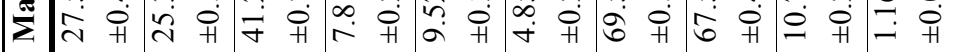

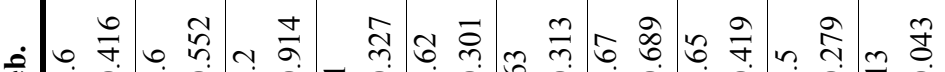

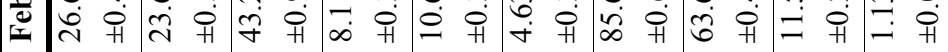
$\dot{0}$ प

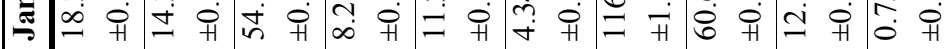

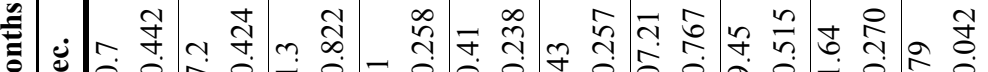

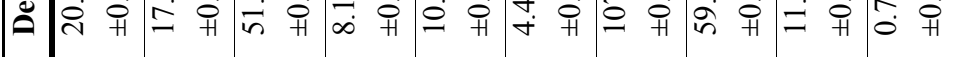

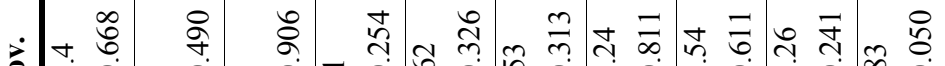

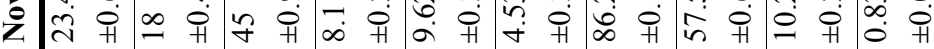
+ m

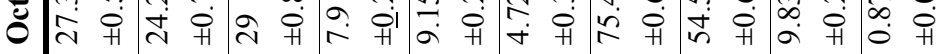

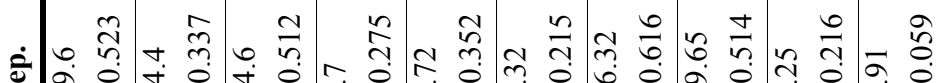

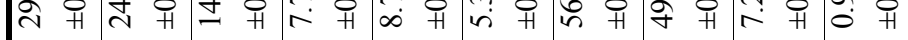
कi

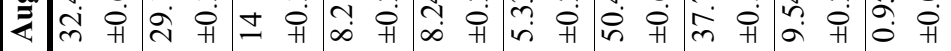

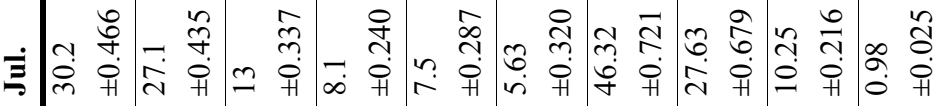

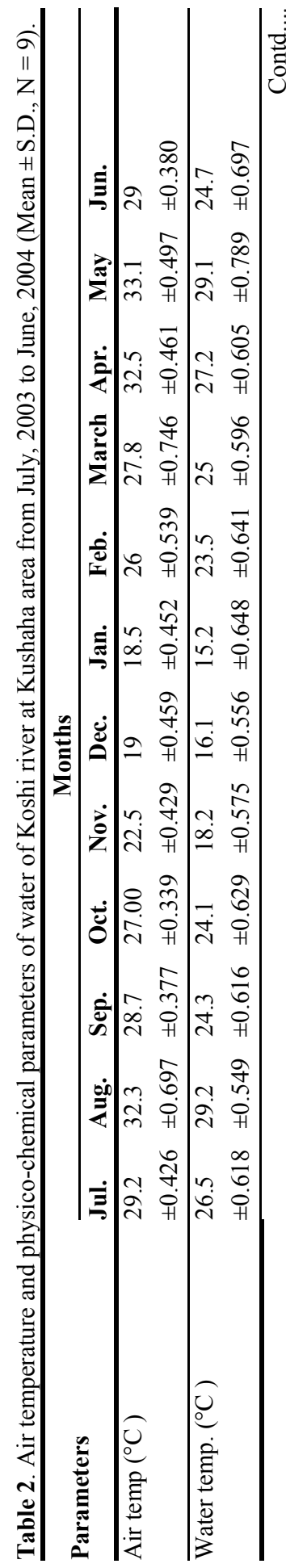


D. Thapa Chhetry and J. Pal / Our Nature (2011) 9: 156-167

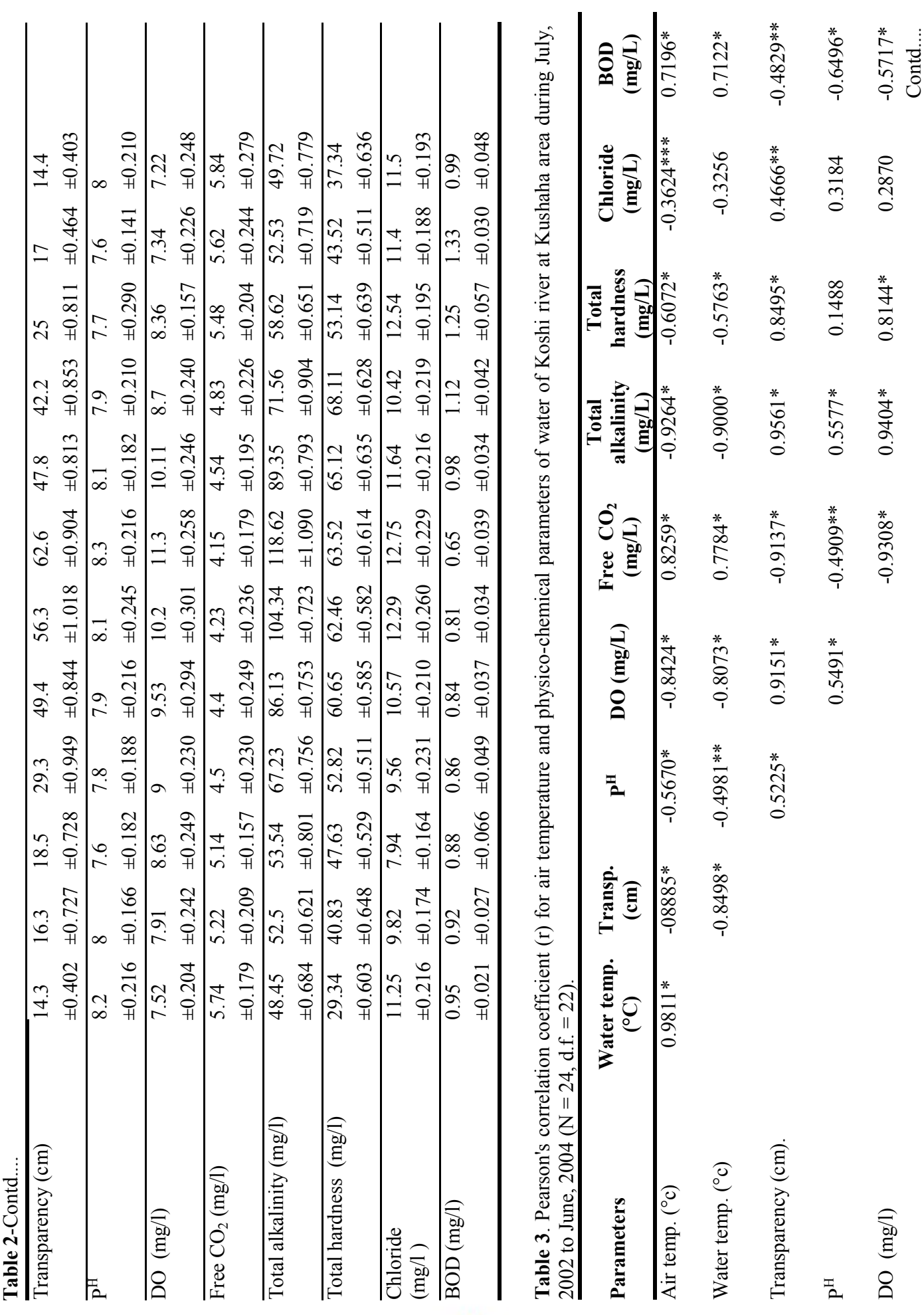


D. Thapa Chhetry and J. Pal / Our Nature (2011) 9: 156-167

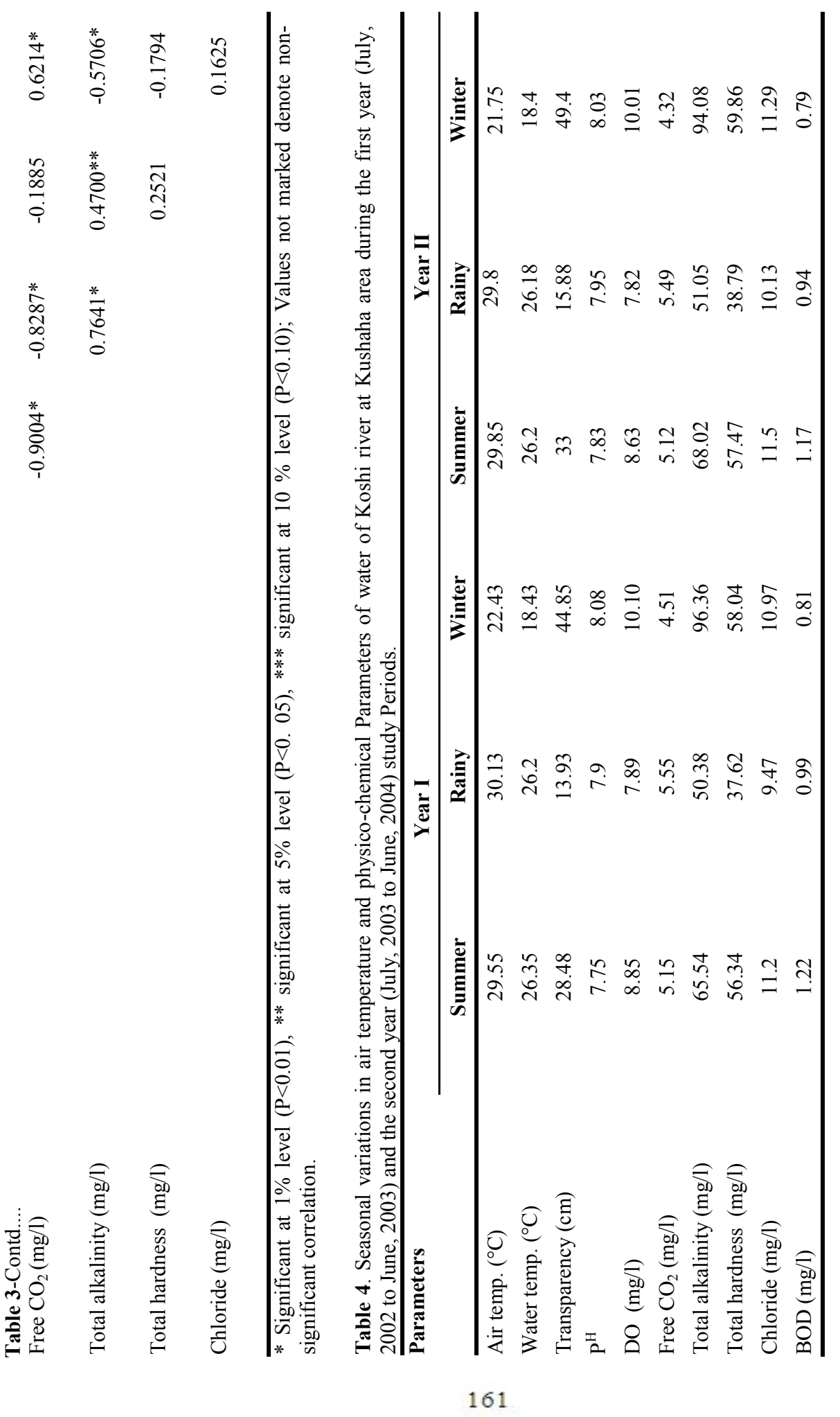




\section{Thapa Chhetry and J. Pal / Our Nature (2011) 9: 156-167}

period, the maximum transparency was $62.6 \pm 0.904 \mathrm{~cm}$ in the month of January and minimum $14.3 \pm 0.402 \mathrm{~cm}$ in the month of July. The transparency had positive and significant correlation with $\mathrm{pH}(\mathrm{r}=0.5225$, $\mathrm{P}<0.0 .1)$, dissolved oxygen $(\mathrm{r}=0.9151$, $\mathrm{P}<0.01)$, total alkalinity $(\mathrm{r}=0.9561$, $\mathrm{P}<0.01)$, total hardness $(\mathrm{r}=0.8495, \mathrm{P}<0.01)$ and chloride $(\mathrm{r}=0.4666, \mathrm{P}<0.05)$, but inverse and significant correlation with free carbon dioxide $(\mathrm{r}=-0.9137, \mathrm{P}<0.01)$ and biological oxygen demand $(\mathrm{r}=-0.4829$, $\mathrm{P}<0.05)$ (Tab. 3). The maximum value of transparency was in winter followed by summer and rainy seasons during the first and the second year study periods.

\section{pH}

The $\mathrm{pH}$ of water of the Koshi river increased a little in August then a slight decrease was recorded in September. Again it increased from October to January then decreased from February to May and increased from June to July during the first year study period (Tab. 1). The minimum $\mathrm{pH}$ was $7.5 \pm 0.309$ in the month of May and maximum $8.2 \pm 0.231$ in August and January, respectively during the first year study period. During the second year study period, it decreased from August to September then increased from October to January. Again it decreased from February to May then increased from June to July (Tab. 2). The minimum $\mathrm{pH}$ was $7.6 \pm 0.182$ and $7.6 \pm 0.141$ in the month of September and May, respectively and maximum $8.3 \pm 0.216$ in January during the second year study period. $\mathrm{pH}$ had positive and significant correlation with dissolved oxygen $(\mathrm{r}=$ $0.5491, \mathrm{P}<0.01)$ and total alkalinity $(\mathrm{r}=$ $0.5577, \mathrm{P}<0.01$ ) but inverse and significant correlation with free carbon dioxide $(\mathrm{r}=$ $0.4909, \quad \mathrm{P}<0.05)$ and biological oxygen demand $(r=-0.6496, P<0.01)($ Tab. 3$)$. The $\mathrm{pH}$ was highest in winter followed by rainy and summer seasons during the first and the second year study periods.

\section{Dissolved oxygen}

The dissolved oxygen increased from July to January and decreased from February to June during the first year (Tab. 1) and the second year study periods (Tab. 2). The maximum dissolved oxygen was $11.23 \pm 0.297 \mathrm{mg} / \mathrm{l}$ in the month of January and the minimum $7.11 \pm 0.335 \mathrm{mg} / \mathrm{l}$ in the month of June during the first year study period. In the second year study period, the maximum dissolved oxygen was $11.3 \pm 0.258 \mathrm{mg} / \mathrm{l}$ in the month of January and minimum $7.22 \pm 0.248 \mathrm{mg} / \mathrm{l}$ in the month of June. The dissolved oxygen showed positive and significant correlation with total alkalinity $(\mathrm{r}=0.9404, \mathrm{P}<0.01)$ and total hardness $(\mathrm{r}=0.8144, \mathrm{P}<0.01)$ but inverse and significant correlation with free carbon dioxide $(\mathrm{r}=-0.9308, \mathrm{P}<0.01)$ and biological oxygen demand $(\mathrm{r}=-0.5717$, $\mathrm{P}<0.01)$ (Tab. 3). The maximum dissolved oxygen was in winter followed by summer and rainy seasons during the first and the second year study periods.

\section{Free carbon dioxide}

The free carbon dioxide decreased from July to January then increased from February to June during the first year (Tab. 1) and the second year study periods (Tab. 2 ). The maximum free carbon dioxide was $5.92 \pm 0.326 \mathrm{mg} / \mathrm{l}$ in the month of June and minimum $4.34 \pm 0.287 \mathrm{mg} / 1$ in the month of January during the first year study period. During the second year study period, the maximum free carbon dioxide was $5.84 \pm 0.279 \mathrm{mg} / \mathrm{l}$ in the month of June and minimum $4.15 \pm 0.179 \mathrm{mg} / 1$ in the month of 


\section{Thapa Chhetry and J. Pal / Our Nature (2011) 9: 156-167}

January. Free carbon dioxide showed positive and significant correlation with biological oxygen demand $(\mathrm{r}=0.6214$, $\mathrm{P}<0.01)$ but inverse and significant correlation with total alkalinity $(r=-0.9004$, $\mathrm{P}<0.01)$ and total hardness $(\mathrm{r}=-0.8287$, $\mathrm{P}<0.01$ ) (Tab. 3). Maximum value of free carbon dioxide was in rainy season followed by summer and lowest in winter season during the first and the second year study periods.

\section{Total alkalinity}

The total alkalinity increased from August to January and decreased from February to July during the first year (Tab. 1) and the second year study periods (Tab. 2). The maximum total alkalinity was $116.52 \pm 1.045 \mathrm{mg} / \mathrm{l}$ in January and minimum $46.32 \pm 721 \mathrm{mg} / \mathrm{l}$ in July during the first year study period. During the second year study period, the maximum total alkalinity was $118.62 \pm 1.090 \mathrm{mg} / \mathrm{l}$ in the month of January and minimum $48.45 \pm 0.684 \mathrm{mg} / 1$ in the month of July. It had positive and significant correlation with total hardness $(\mathrm{r}=0.7641, \mathrm{P}<0.01)$ and chloride $(\mathrm{r}=0.4700, \mathrm{P}<0.05)$ but inverse and significant correlation with biological oxygen demand $(\mathrm{r}=-0.5706, \mathrm{P}<0.01)(\mathrm{Tab}$. $3)$. The maximum total alkalinity was in winter followed by summer and rainy seasons during the whole study period.

\section{Total hardness}

The total hardness increased from August to March and decreased from April to July during the first year (Tab. 1) and the second year study periods (Tab. 2). The maximum total hardness was $67.55 \pm 0.463 \mathrm{mg} / \mathrm{l}$ in March and minimum $27.63 \pm 0.679 \mathrm{mg} / 1$ in July during the first year study period. During the second year study period, the maximum total hardness was $68.11 \pm 0.628$ $\mathrm{mg} / 1$ in March and minimum $29.34 \pm 0.603$ $\mathrm{mg} / \mathrm{l}$ in July. It had positive and significant correlation with transparency $(\mathrm{r}=0.8495$, $\mathrm{P}<0.01)$, dissolved oxygen $(\mathrm{r}=0.8144$, $\mathrm{P}<0.01)$ and total alkalinity $(\mathrm{r}=0.7641$, $\mathrm{P}<0.01)$ and inverse and significant correlation with air temperature $(\mathrm{r}=$ $0.6072, \mathrm{P}<0.01)$, water temperature $(\mathrm{r}=$ $0.5763, \mathrm{P}<0.01)$, and free carbon dioxide ( $\mathrm{r}$ $=-0.8287, \mathrm{P}<0.01)($ Tab. 3). The maximum total hardness was in winter followed by summer and rainy seasons during the whole study period.

\section{Chloride}

The maximum chloride was $12.15 \pm 0.260$ $\mathrm{mg} / 1$ in January and minimum $7.25 \pm 0.216$ $\mathrm{mg} / \mathrm{l}$ in September during the first year study period (Tab. 1). During the second year study period, the maximum chloride was $12.75 \pm 0.229 \mathrm{mg} / 1$ in the month of January and minimum $7.94 \pm 0.164 \mathrm{mg} / \mathrm{lin}$ the month of September (Tab. 2). It had positive and significant correlation with transparency $(\mathrm{r}=0.4666, \mathrm{P}<0.05)$ and total alkalinity $(\mathrm{r}=0.4700, \mathrm{P}<0.05)$, and inverse and significant correlation with air temperature $(\mathrm{r}=-0.3624, \mathrm{P}<0.10)($ Tab. 3). The maximum value of chloride was in summer followed by winter and minimum in rainy season during the first and the second year study periods.

\section{Biological oxygen demand}

The biological oxygen demand decreased from July to January and increased from February to May. Again it decreased a little in June during the first year (Tab. 1) and second year study periods (Tab. 2). The maximum biological oxygen demand was $1.35 \pm 0.062 \mathrm{mg} / \mathrm{l}$ in May and minimum $0.75 \pm 0.042 \mathrm{mg} / \mathrm{l}$ in January during the first 


\section{Thapa Chhetry and J. Pal / Our Nature (2011) 9: 156-167}

year study period. During the second year study period, the maximum biological oxygen demand was $1.33 \pm 0.030 \mathrm{mg} / \mathrm{l}$ in the month of May and minimum $0.65 \pm 0.039$ $\mathrm{mg} / \mathrm{l}$ in January. It had positive and significant correlation with air temperature $(\mathrm{r}=0.7196, \mathrm{P}<0.01)$, water temperature $(\mathrm{r}=$ $0.7122, \mathrm{P}<0.01)$ and free carbon dioxide $(\mathrm{r}$ $=0.6214, \quad \mathrm{P}<0.01)$ but inverse and significant correlation with transparency $(\mathrm{r}$ $=-0.4829 \mathrm{P}<0.05), \mathrm{pH} \quad(\mathrm{r}=-0.6496$, $\mathrm{P}<0.01)$, dissolved oxygen $(\mathrm{r}=-0.5717$, $\mathrm{P}<0.01)$ and total alkalinity $(\mathrm{r}=-0.5706$, $\mathrm{P}<0.01$ ) (Tab. 3). The maximum value of biological oxygen demand was in summer followed by rainy and winter seasons during the first and the second year study periods (Tab. 4).

\section{Discussion}

The highest air temperature was recorded in the month of May (Tabs. 1, 2). When data on monthly air temperature of the first year (July, 2002 to June, 2003) and the second year (July, 2003 to June, 2004) study periods were pooled in seasonal values, very little difference observed in rainy and summer season (Tab. 4) due to its geographical location. Air temperature showed positive and significant correlation with water temperature (Tab. 3). Chakraborty et al. (1959), Kant and Anand (1978) and Rawat et al. (1995) also obtained strong positive significant correlation between air and water temperatures.

Generally, water temperature is influenced by air temperature and intensity of solar radiation. It was highest in summer and lowest in winter (Tab. 4). Highest value recorded in summer might be due to high air temperature and greater light penetration and comparatively low volume of water than rainy season. The water temperature showed positive and significant correlation with free carbon dioxide and biological oxygen demand but had inverse and significant correlation with transparency, $\mathrm{pH}$, dissolved oxygen, total alkalinity and total hardness. Bose and Gorai (1993) reported negative significant correlation between water temperature and dissolved oxygen. Welch (1952) and Munawar (1970) have observed that shallower the water body more quickly it reacts to the change in the temperature.

The maximum Secchi disc transparency was recorded in winter followed by summer and rainy seasons during whole study period (Tab. 4). The maximum transparency was in winter due to lesser amount of suspended organic and inorganic materials and absence of rain. Transparency is influenced mainly by suspended organic matter (Green, 1974). Higher transparency during winter months was recorded by Singh (1990), Rawat et al. (1995) and Mishra et al. (1999). In this study minimum transparency was recorded in the rainy season may be due to more sand particles and colloidal particles carried by the rain water. Similar trends were observed by Singh (1995) and Mishra et al. (1998).

The maximum $\mathrm{pH}$ of present study was in winter season followed by rainy and summer seasons (Tab. 4). The maximum $\mathrm{pH}$ in winter season may be attributed to algal blooms because Roy (1955) had shown that the higher $\mathrm{pH}$ is associated with the phytoplankton maxima. The minimum $\mathrm{pH}$ recorded in summer may be due to low photosynthesis. Several workers have reported low $\mathrm{pH}$ during the low photosynthesis due to the formation of carbonic acid (Hannan and Yong, 1974; Cabecadas and Brogueira, 1987; Bais et al., 


\section{Thapa Chhetry and J. Pal / Our Nature (2011) 9: 156-167}

1995). But, Gautam (1990) reported highest $\mathrm{pH}$ in summer and lowest in rainy season. The $\mathrm{pH}$ showed positive and significant correlation with dissolved oxygen and total alkalinity. Rawat et al. (1995) reported positive correlation with total alkalinity $(\mathrm{r}=$ $0.523, \mathrm{P}<0.05)$ and inverse correlation with water temperature.

The maximum dissolved oxygen found in winter season may be due to low temperature. Similar observations were made by Moitra and Bhattacharya (1965). The minimum dissolved oxygen was found in summer due to high temperature, and higher microbial demand of oxygen for decomposition of suspended organic matter (Bhowmick and Singh, 1985; Palharya and Malviya, 1988). Elmore and West (1961) stated that an increase in temperature of water results in the decrease of dissolved oxygen content of water. The dissolved oxygen showed inverse and significant correlation with water temperature, free carbon dioxide and biological oxygen demand. Bose and Gorai (1993) also reported inverse and significant correlation of dissolved oxygen with water temperature. Jindal and Kumar (1993) reported inverse correlation of dissolved oxygen with water temperature.

In this study the minimum free carbon dioxide was found in winter season. Pahwa and Mehrotra (1966), Gautam (1990) and Pandey and Lal (1995) also found minimum free carbon dioxide in winter season. Free carbon dioxide of water showed positive and significant correlation with water temperature and biological oxygen demand, and inverse and significant correlation with dissolved oxygen (Tab. 3). Pahwa and Mehrotra (1966) observed inverse correlation of free $\mathrm{CO}_{2}$ with dissolved oxygen.
The total alkalinity observed was maximum in winter season due to high $\mathrm{pH}$. Chakraborty et al. (1959), Singh (1990) and Mishra et al. (1998) also reported maximum total alkalinity during winter. Water bodies having total alkalinity from 40 to $90 \mathrm{mg} / \mathrm{l}$ is considered as medium productive and above $90 \mathrm{mg} / \mathrm{l}$ as highly productive (Jhingran, 1991). This investigation showed that the study area is suitable for aquatic production.

Maximum total hardness in winter season might be due to low volume of water and slow current of water. Similar results were obtained by Misra et al. (1999). Minimum quantity in rainy season may be due to more dilution of water (Patralekh, 1994). Ruttner (1953) also recorded similar relationship.

Seasonally, the maximum chloride content was recorded in summer followed by winter and rainy seasons (Tab. 4). The maximum quantity of chloride recorded in summer season may be due to low volume of water, high temperature and high rate of decomposition of organic matters. Chloride concentration indicates the presence of organic waste of animal origin (Thresh et al., 1949). Munawar (1970) has suggested that higher concentration of chloride in water is an index of pollution of animal origin and there is a direct relation between chloride concentration and pollution level.

The maximum BOD was recorded in summer followed by rainy and winter seasons (Tab. 4). The maximum BOD obtained in summer may be due to low volume of water and high content of organic matter whereas minimum obtained in winter may be due to low temperature and retarded microbial activity for the decomposition of organic matters. Similar observations were also made by Singh (1995). Ray and David 


\section{Thapa Chhetry and J. Pal / Our Nature (2011) 9: 156-167}

(1966) opined that high BOD value indicates organic waste pollution.

\section{Acknowledgements}

We are thankful to Prof. Dr. S. Jha, Head, Department of Botany, P.G. Campus for his kind co-operation during manuscript preparation. We also thank Dr. B.R. Subba, Department of Zoology, P.G. Campus for field work as well as providing valuable literature. Thanks are also due to University Grants Commission, Nepal for the financial assistance.

\section{References}

Adoni, A.D., G. Joshi, K. Ghosh, S.K. Chourasia, A.K. Vaishya, M. Yadav and J.D. Allan 1985. Stream ecology. Chapman and Hall, London.

APHA 1998. Standard methods for examination of water and waste water. $20^{\text {th }}$ Edn., Washington, USA.

Aryal, S. and P. Lacoul 1996. Water quality and diversity of diatoms in Punyamati river, Nepal. Ecoprint 3: 45-49.

Bais, V.S., N.C. Agrawal and A. Tazeen 1995. Comparative study on seasonal changes in phytoplankton community in the Sagar lake and Military Engineering lake (M.P.). J. Freshwater Biol. 7: 19-25.

Bhowmick, B.N. and A.S. Singh 1985. Effect of sewage on physico- chemical characteristics and bacterial population in river Ganga at Patna. Indian J. Ecol. 12: 141-146.

Bose, S.K. and A.C. Gorai 1993. Seasonal fluctuations of plankton in relation to physicochemical parameters of a freshwater tank of Dhanbad, India. J. Freshwater Biol. 5: 133-140.

Cabecadas, G. and M.J. Brogueira 1987. Primary production and pigments in three low alkalinity connected reservoirs receiving mine wastes. Hydrobiol. 144: 173-182.

Chakraborty, R., D.P. Roy and S.B. Singh 1959. A quantitative study of the plankton and physicochemical conditions of the river Jamuna at Allahabad in 1954-55. Indian J. Fish. 6: 186-203.

Elmore, H.L. and W.F. West 1961. Effect of water temperature on stream reaeration. IASCF 87 SA 6 : 59.

Gautam, A. 1990. Ecology and pollution of mountain waters. Ashish Publ. House, New Delhi.
Green, J.D. 1974. Ecological studies on crater lakes in west Cameroon, Debunsha lake. J. Zool. 17: 199223.

Hannan, H.H. and W.J. Yong 1974. The influence of a deep storage reservoir on the physico-chemical limnology of a central Taxas river. Hydrobiol. 44: 177-207.

Jhingran, V.G. 1991. Fish and fisheries of India. $3^{\text {rd }}$ edn., Hindustan Publ., New Delhi.

Jindal, R. and R. Kumar 1993. Limnology of a freshwater pond of Nalagarh (Himachal Pradesh, India). 1. Physico-chemical complexes. In Advances in limnology (Ed. H.R. Singh) Narendra Publ. House, Delhi. pp. 107-112.

Kant, S. and V.K. Anand 1978. Interrelationship of phytoplankton and physical factors in Ansar lake, Jammu, India. J. Ecol. 5: 134-140.

Loffler, H. 1969. High altitude lakes in Mt. Everest region. Verh. nternat. Verein Limnol. 17: 373-385.

Lohman, K., M.F.K. Jones, D.G. Swar, M.A. Pamperl and B.J. Brazos 1988. Pre and post monsoon limnological characteristics of lakes in the Pokhara and Kathmandu valleys, Nepal. Verh. Internat. Verein. Limnol. 23: 558-565.

McEachern, P. 1994. Limnology and the natural wetlands survey. In Safeguarding wetlands in Nepal (Eds. B. Bhandari, T.B. Shrestha and P. McEachern), IUCN, Nepal. pp. 89-103.

Michael, P. 1984. Ecological methods for field and laboratory investigation. Tata Mc Graw- Hill Publishing Co., New Delhi.

Mishra, A.P., B.K. Bora and M. Sharma 1998. Investigations on the seasonal variation of certain physico-chemical parameters of a Beel, Assam, India. J. Freshwater Biol. 10: 83-87.

Mishra, A.P., B.K. Bora and M. Sharma 1999. Limnological investigation of a freshwater tributary, Assam, India. J. Freshwater Biol. 11: 15.

Moitra, S.K. and B.K. Bhattacharya 1965. Some hydrobiological factors affecting plankton production in fish pond at Kalyani, W.B., India. Ichthyol. 4: 8-12.

Munawar, M. 1970. Limnological studies of fresh water ponds of Hyderabad, India-I. The Biotope. Hydrobiol. 35: 127-162.

Ormerod, S.J., S.T. Buckton, P.A. Brewin, A. Jenkins, R.C. Johnson, U. Juttner and A. Suren 1996. Biodiversity, chemistry and structure in streams of the Nepalese Himalaya. In Proc. Inter. Confer Ecohydrol. High Mount. Kathmandu. (Eds. S.R. Chalise and N.R. Khanal). pp. 1197-1200. 


\section{Thapa Chhetry and J. Pal / Our Nature (2011) 9: 156-167}

Pahwa, D.V. and S.N. Mehrotra 1966. Observations on fluctuations in abundance of plankton in relation to certain hydrobiological conditions of river Ganga. Proc. Nat. Acad. Sci., India. 36B 2: 57-189.

Palharya, J.P. and S. Malviya 1988. Pollution of the Narmada at Hoshangabad in Madhya Pradesh and suggested measures for control. In Ecology and pollution of Indian rivers (Ed. R.K. Trivedy), Ashish Publishing House, New Delhi. pp. 55-86.

Pandey, K.K. and M.S. Lal 1995. Limnological studies of Garhwal Himalayan hillstream Khanda gad: Seasonal fluctuation in abiotic profile. $J$. Freshwater Biol. 7: 7-11.

Patralekh, L.N. 1994. Comparative account of physico-chemical properties of three freshwater ecosystems. J. Freshwater Biol. 6: 115-119.

Rawat, M.S., C.P. Juyal and R.C. Sharma 1995. Morphometry and physico-chemical profile of high altitude lake Deoria Tal of Garwal Himalaya. J. Freshwater Biol. 7: 1-6.

Ray, P. and A. David 1966. Effect of industrial wastes and sewage upon the chemical and biological composition and fisheries of the river Ganga at Kanpur. Environ. Hlth. 8: 307-339.

Roy, H. 1955. Plankton ecology of river Hooghly (West Bengal). Ecol. 36: 169-744.

Ruttner, F. 1953. Fundamentals of limnology. University of Toronto Press, Toronto.

Singh, H.P. 1990. Distribution and seasonal fluctuation of certain physico-chemical features in the Brahmaputra river. J. Assam Sci. Soc. 32: 6469.

Singh, M. 1995. Impact of human activities on the physico-chemical conditions of two fish ponds at Patna, India. J. Freshwater Biol. 7: 13-17.

Thresh, J.C., J.F. Beale and E.V. Suckling 1949. The examination of water and water supplies (Ed. E.W. Taylor). J. and A. Churchill Ltd., London.

Trivedy, R.K. and P.K. Goel 1984. Chemical and biological methods for water pollution studies. Environmental Publications, Karad, India.

Welch P.S. 1952. Limnological methods. $2^{\text {nd }}$ Edn., MC. Graw Hill Book Co., New York. 